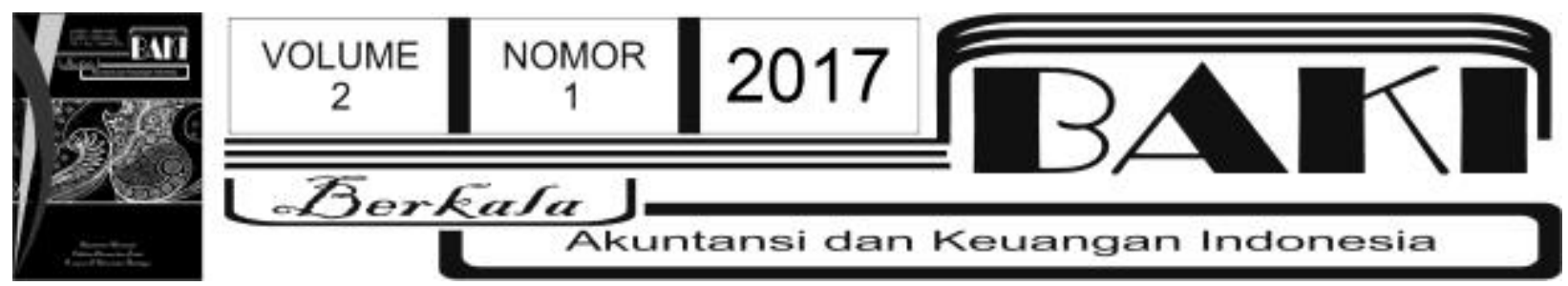

\title{
Model Pemeringkatan Perusahaan Berdasarkan Analisis dan Pemberian Bobot Pada Kualitas Karakteristik Laporan Keuangan
}

\author{
Christina Aprilia ${ }^{1}$ \\ Basuki ${ }^{1,2}$ \\ ${ }^{1}$ FEB Universitas Airlangga \\ 2basuki@feb.unair.ac.id
}

INFO ARTIKEL

\begin{tabular}{l} 
Histori Artikel: \\
Tanggal Masuk 13 April 2017 \\
Tanggal Diterima 26 April 2017 \\
Tersedia Online 9 Mei 2017 \\
\hline Kata Kunci: \\
kualitas informasi; \\
laporan keuangan; karakteristik \\
kualitatif; rating
\end{tabular}

\begin{abstract}
A B STRAK
Tujuan penelitian ini adalah untuk menyediakan alternatif pemeringkatan perusahaan berdasarkan analisis pada kualitas karakteristik aporan keuangan. Penelitian ini menggunakan pendekatan exploratory non mainstream dan data dikumpulkan dengan menggunakan metode dokumentasi. Subjek penelitian adalah sebanyak 438 perusahaan yang ada di Indonesia. Hasil menunjukkan bahwa perusahaan yang memiliki peringkat baik dan menegah dalam karakterisk kualitatifnya, sejalan dengan perusahaan yang dirating dengan menggunakan indikator lain seperti kepatuhan terhadap GCG, resilience of economy, kinerja keuangan, serta pola aktivitas saham pada pasar modal. Penelitian ini memberikan implikasi bahwa pemeringkatan yang diajukan merupakan alternatif pemeringkatan yang lebih sederhana dan mudah, namun tetap memiliki manfaat yang berbeda bagi para pengambil keputusan.
\end{abstract}

\section{Pendahuluan}

Informasi yang terstandarisasi, sederhana tetapi berkualitas akan membantu pengambil keputusan dari beragam latar belakang. Informasi berkualitas tinggi memegang peran penting sehingga harus bisa diperoleh oleh seluruh pengambil keputusan. Cara mudah dan hemat waktu yang sering digunakan pengambil keputusan dengan beragam latar belakang tersebut adalah dengan menggunakan analisis dari intermediari. Mekanisme pihak intermediari yang dianggap cukup efektif adalah dengan menggunakan signal yakni menggunakan pihak perantara untuk bisa melakukan analisis dan memberikan komentar ataupun jaminan untuk bisa selanjutnya diungkapkan kepada publik. Mekanisme ini sudah berjalan lama untuk pengambil keputusan dalam pemberian hutang yaitu dengan menggunakan debt rating, tetapi cara ini belum banyak diterapkan bagi pemegang saham dan investor ekuitas. 
Salah satu sumber informasi yang dijadikan pedoman investor adalah laporan keuangan. Tujuan utama dari pelaporan keuangan adalah untuk memberikan informasi keuangan berkualitas tinggi mengenai sebuah entitas, terutama yang terkait dengan ekonomi (SAK 2012). Menghasilkan laporan keuangan yang memiliki kualitas tinggi akan memengaruhi para pemilik dan atau penyedia modal dan pemangku kepentingan lainnya (stakeholder) dalam melakukan investasi, kredit, dan alokasi sumber daya kepada entitas yang membutuhkan dan pada akhirnya akan berguna untuk pengambilan keputusan ekonomi dan meningkatkan efisiensi pasar secara keseluruhan (Scott 2012: 463).

Pemberian peringkat (rating) di Indonesia dengan membandingkan kualitas informasi Laporan Keuangan sudah dilakukan oleh beberapa instansi terpisah, seperti Annual Report Award (ARA) yang dilakukan oleh Otoritas Jasa Keuangan (OJK) yang mengangkat pembobotan berdasar pada indikator Good Corporate Governance (GCG). Majalah SWA dan FORBES juga memberikan rating pada perusahaan melalui ketahanan ekonomi dan konsistensi pemberian keuntungan. Penilaian indikator yang berbeda-beda dapat diterima karena dilihat sebagai tambahan informasi yang saling melengkapi dan tetap memenuhi peran intermediari untuk memberikan informasi keuangan berkualitas. Penilai kualitas perusahaan di Indonesia yang menggunakan metode yang beragam, misal penilai kualitas seperti Annual Report Award (ARA) yang melihat kualitas Laporan Keuangan dengan menggunakan cara penyampaian laporan tahunan dengan berdasarkan Corporate Governanace, majalah Forbes yang memberikan peringkat kualitas Perusahaan (bukan Laporan keuangan) berdasarkan ketahanan ekonomi disaat ketidakpastian global, dan majalah SWA memiliki metode lain lagi dalam menilai kualitas sebuah perusahaan (data keuangan), yakni dengan menggunakan metode Wealth Added Index (WAl) yang menggambarkan peningkatan kekayaan pemegang saham.

Berdasar keadaan tersebut, peneliti melihat adanya celah penelitian yang bisa dilakukan untuk mencari alternatif pemeringkatan yang terstandarisasi, sederhana tetapi berkualitas. Pemeringkatan alternatif ini dengan cara memberikan informasi kualitas Laporan Keuangan dengan menggunakan karakteristik kualitatif sebagai indikator yang harus dipenuhi sebuah Laporan Keuangan berkualitas. Beest et al. (2009) memang sudah menggunakan karakteristik kualitatif sebagai indikator untuk mengukur apakah sebuah Laporan Keuangan berkualitas atau tidak, namun penelitian Beest ini terhenti pada kesimpulan compliance atau kepatuhan. Penelitian ini dikembangkan menjadi informasi rating yang membandingkan kualitas satu perusahaan dengan lainnya dalam satu populasi. Peneliti menggunakan kembali pertanyaan yang digunakan Beest et al. (2009) untuk mengukur kualitas karakteristik secara spesifik dalam Laporan keuangan.

Di Indonesia kualitas laporan keuangan bagi perusahaan terbuka sudah diatur dengan mendetail dalam kerangka konseptual SAK dan Peraturan Bapepam Nomor VIII.G.7 Kep- 347/BL/2012, serta Peraturan Bapepam Nomor X.K.6 Kep-431/BL/2012 mengenai pedoman penyajian laporan keuangan. Indikator ini juga dipakai ARA sebagai persyaratan agar sebuah laporan keuangan bisa dikatakan berkualitas. Peneliti ikut menggunakan indikator tersebut yang diselaraskan untuk 
menjawab karakteristik kualitas yang harus dipenuhi oleh perusahaan agar laporan keuangan mereka dapat dikatakan berkualitas.

Berdasarkan latar belakang yang telah diuraikan di atas, maka rumusan masalah penelitian adalah "Bagaimana merumuskan alternatif peratingan dengan berbasis pada kualitas karakteristik kualitatif laporan keuangan perusahaan yang terdaftar di Bursa Efek Indonesia?". Tujuan penelitian ini adalah menawarkan dan memberikan alternatif peratingan berdasar atas pada karakteristik kualitatif laporan keuangan.

\section{Tinjauan Pustaka}

Tidak sedikit penelitian yang bertema terkait dengan kualitas laporan keuangan. Pendekatan melalui pola serta perilaku pengambil keputusan sebagai pengguna informasi keuangan menjadi hal yang tidak habis untuk dieksplorasi. Penelitian yang paling sering dilakukan adalah dengan mengukur kualitas informasi laporan keuangan dari data keuangan, misalnya hubungan laba dengan reaksi pasar modal (Penman 2007), atau laba berasosiasi secara kuat dengan arus kas operasi di masa yang akan datang (Dechow dan Dichev 2002), dan hubungan laba dengan imbalan pasar yang menunjukkan informasi pelaporan keuangan tersebut semakin tinggi (Leuz dan Verrecchia 2000). Penelitian lain yang dilakukan oleh Verrecchia (2001) menggambarkan bahwa penyediaan pengungkapan akuntansi berkualitas akan cenderung meningkatkan efisiensi pasar saham, sehingga kualitas itu sendiri bisa dilihat dengan mengukur efisiensi pasar. Penelitian Beaver (1968) dan Dechow dan Dichev (2002) setuju bahwa kualitas lebih mengarah pada apa yang disampaikan oleh manajer dimana mereka menggunakan kendali untuk mengelola pendapatan (Dechow dan Dichev 2002; Healy dan Palepu 2001).

Usaha yang dilakukan untuk mengukur kualitas informasi, tidak hanya menggunakan data kuantitatif tetapi penelitian lanjutan melihat bahwa kualitas itu bisa diukur secara mendalam dengan data kualitatif. Penelitian Healy dan Palepu (2001) menunjukkan bahwa harga saham dan angka akuntansi membutuhkan proses panjang dan tidak bisa secara instan menjadi variable pengukuran. Sejalan dengan kesimpulan yang diambil oleh Penman dan Zhang (2002) dan Penman (2007) yang menjadi tema dalam penelitian ini, maka disepakati bersama bahwa harga di pasar tidak sepenuhnya terdapat di laporan keuangan, dan bukti baru bahwa harga saham dan rekomendasi konsensus tidak sepenuhnya mengandalkan informasi laporan keuangan. Sehingga kurang tepat jika mengukur kualitas yang ada dalam laporan keuangan hanya melalui pergerakan harga di pasar.

Kualitas pelaporan keuangan adalah konsep yang lebih luas yang tidak hanya mengacu pada informasi keuangan, tetapi juga untuk pengungkapan, dan informasi non-keuangan lainnya yang berguna untuk pengambilan keputusan disertakan dalam laporan seperti yang diungkapkan dalam penelitian McDaniel et al. (2002). Penelitian Beest et al. (2009) adalah salah satu yang menganalisis dan membuktikan bahwa komponen-komponen yang ada dalam standar sudah cukup mampu dan valid untuk menggambarkan kualitas sebuah laporan keuangan. Pengukuran kualitas dengan 
menggunakan indikator karakteristik kualitatif sebagai komponen utama menjadi basis awal ide penelitian ini melanjutkkan penelitain sebelumnya yang berusaha menemukan metode pengukuran kualitas informasi yang terkandung dalam laporan keuangan.

Perusahaan memberikan informasi melalui laporan keuangan yang diatur oleh standar, ataupun melalui mekanisme lain bersifat langsung "eksplisit" melalui pengungkapan informasi sukarela seperti catatan kaki, dan analisis diskusi managemen, dan melalui mekanisme yang bersiat "implicit" seperti signaling (Scott 2012: 130). Secara ideal, standar akuntansi melalui kerangka konseptual yang ada sudah menjawab bagaimana seharusnya manager menyampaikan informasi keuangan kepada outside stakeholder, tetapi sayangnya keadaan pasar yang tidak seimbang pada akhirnya menyebabkan distorsi informasi, dan untuk mendapatkan selisih informasi dalam distorsi tersebut maka investor harus mengeluarkan biaya tambahan dan tentu saja menyebabkan nilai perusahaan yang tergambar di pasar saham menjadi salah (Foster 1978; Leuz dan Verrecchia 2000).

Banyak dan beranekaragamnya suatu pasar memperkuat kebutuhan akan sinyal. Sinyal dalam informasi keuangan sendiri adalah informasi yang terkait dengan tindakan yang akan dilakukan oleh manager yang lebih handal yang mungkin saja pilihan itu tidak akan dilakukan oleh manager yang lebih tidak handal (Scott 2012: 475). Spence (1973) juga mengatakan bahwa pasar yang merupakan tempat sinyal itu terjadi sangat berpengaruh terhadap kekuatan sinyal untuk menyampaikan informasi kepada pasar. Rating dan kompetisi atas kualitas yang disajikan dalam laporan keuangan bisa menjadi sinyal yang seharusnya lebih cepat dan sederhana ditangkap oleh pengambil keputusan.

Dari sisi stakeholder sendiri, menurut Bazerman dan Moore (2012: 79) pengambilan keputusan dengan menggunakan analisis kelompok (Joint versus Separate Preference) akan menyebabkan hasil yang berbeda dibandingkan melakukan pengambilan keputusan berdasarkan analisis individual. Efek framing tersebut jika diterapkan dalam laporan keuangan yang memiliki rating akan menunjukkan kualitas laporan keuangan tersebut bisa diperbandingkan dengan populasi dan menghasilkan informasi bahwa laporan keuangan tersebut memang berkualitas.

Mekanisme pihak intermediari yang dianggap cukup efektif adalah dengan menggunakan signaling yakni menggunakan pihak perantara untuk bisa melakukan analisis dan memberikan komentar ataupun jaminan untuk selanjutnya diungkapkan kepada publik. Healy dan Palepu (2001) mencontohkan perusahaan Pattern Corp, dimana pihak perantara yakni lembaga penjamin piutang independen bisa menyelesaikan permasalahan informasi yang lebih efisien dan efektif dibandingkan dengan menggunakan tambahan catatan atas laporan keuangan. Pemberian rating oleh pihak perantara dilihat sebagai cara memberikan sinyal kepada pihak pengguna informasi. Perusahaan yang mendapatkan rating yang cukup tinggi akan dilihat memiliki nilai lebih dibandingkan perusahaan lainnya. Pola pikir ini yang menjadi dasar bagi peneliti untuk melihat keterkaitan antara pemberian rating perusahaan berdasarkan kualitas karakteristik yang bisa menjadi nilai tambah informasi bagi stakeholder, menjadi salah satu bukti pemenuhan bahwa perusahaan dan manager sudah menyampaikan informasi yang cukup kepada pasar dan juga investor. Sinyal melalui rating juga menyampaikan bahwa laporan keuangan yang ada memiliki kualitas yang lebih baik, dan rating yang 
baik dapat menjadi motivasi untuk berkompetisi bagi para manager selaku penyedia laporan keuangan.

Penelitian ini menggunakan asumsi pemberian bobot seperti tampak pada tabel 1. Pembobotan ini memang belum ada dasar-dasar dari penelitian terdahulu. Peneliti justru berusaha secara logis memberi bobot $60 \%$ untuk Kualitas utama (fundamental qualities) dan $40 \%$ untuk Kualitas tambahan (enhancing qualities). Kualitas utama dibagi ke dalam lima sub kategori, sementara kualitas tambahan dibagi dalam empat sub kategori. Justifikasi pembobotan tersebut adalah dikarenakan karakteristik dapat dilihat sebagai sebuah hierarki dimana relevansi dan keandalan adalah dua kualitas utama yang membuat informasi akuntansi berguna untuk pengambilan keputusan (Epstein dan Jermakowicz 2010: 24). Jika salah satu kualitas hilang dari sepotong informasi, informasi menjadi tidak akan berguna (Obaidat 2007). Asumsi pendukung lain adalah bahwa kedua karakteristik ini sudah dipenuhi bila paling tidak sudah memenuhi batas dapat diterimanya sebuah nilai pengambilan suara ( $>50 \%$ ). Dari sudut pandang informasi tentu saja pengambilan keputusan akan lebih baik jika mendapatkan informasi yang memenuhi karakteristik lain yakni memenuhi karakter Comparability, Veriability, Understandability dan Timeliness.

Tabel 2.1. Pembobotan Indikator Karakteristik Kualitas Laporan Keuangan

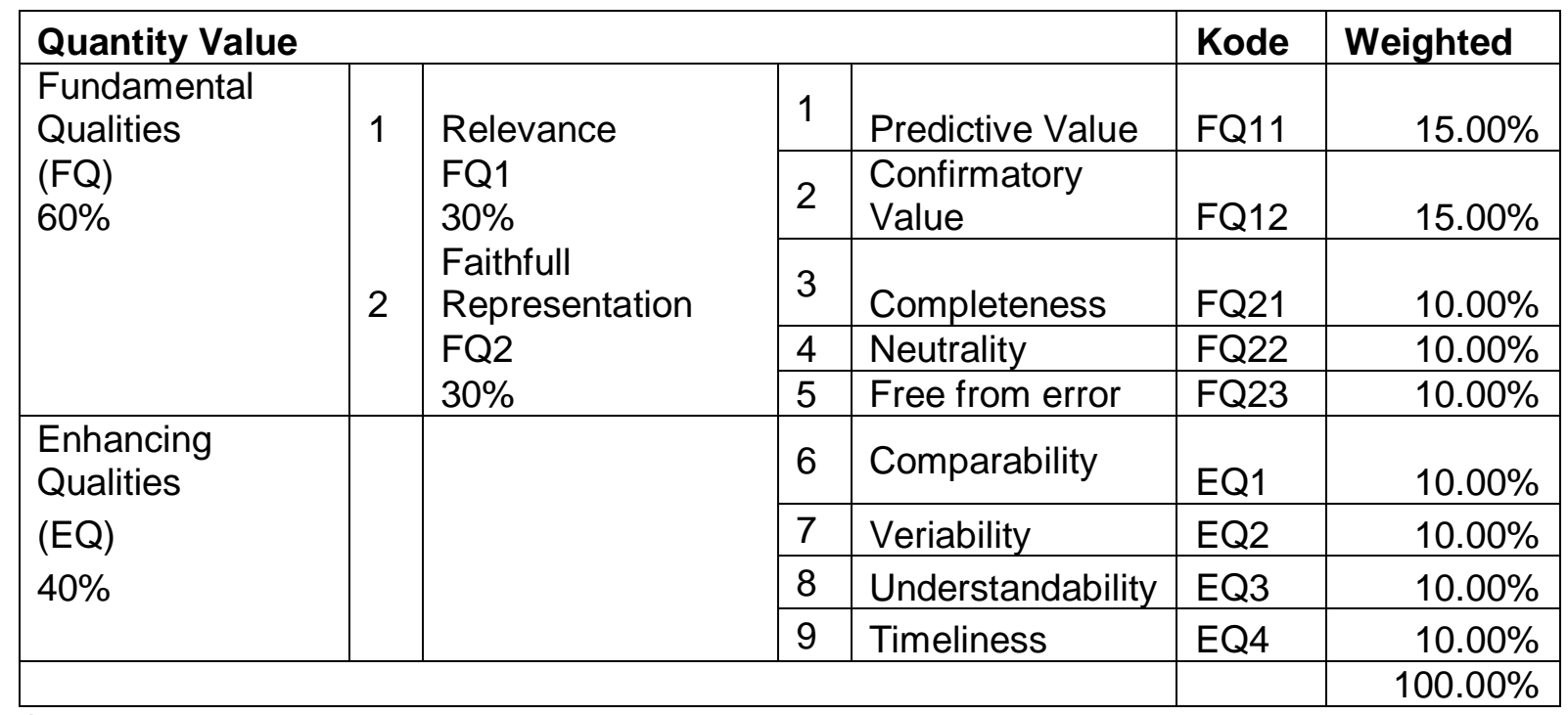

Sumber: Dikembangkan peneliti

Pengukuran akan menggunakan skala attitudinal (Sekaran 2003:196) antara 1-5 dimana menggambarkan respons atas terpenuhinya mekanisme yang digunakan yakni menggabungkan pertanyaan dari penelitian Beest et al., (2009) dan ARA yang berasal dari Peraturan Bapepam Nomor VIII.G.7 Kep- 347/BL/2012, dan Peraturan Bapepam Nomor X.K.6 Kep-431/BL/2012, untuk bisa menjawab indikator pemenuhan kualitas sesuai dengan karakteristik kualitatif Laporan Keuangan.

\section{Metodologi Penelitian}

Penelitian ini menggunakan pendekatan non mainstream yang berusaha mengeksplorasi dan menggali kemungkinan alternatif pemeringkatan dengan menitik beratkan pada pemikiran, 
pemahaman, dan persepsi peneliti (Dialectical Documentation Approach) yang ditunjang oleh landasan teori. Perusahaan yang diteliti adalah seluruh perusahaan Terbuka (Tbk) di Indonesia sampai dengan tahun 2014 sebanyak 508 perusahaan dengan pengecualian perusahaan baru yang Tbk-nya tahun 2013 (31 perusahaan) dan 2014 (23 perusahaan), perusahaan yang delisted pada tahun 2013 (2 perusahaan), dan perusahaan yang datanya tidak tersedia (8 perusahaan). Sehingga dari total 508 perusahaan Tbk yang terdaftar di OJK dikurangi dengan kriteria pengecualian di atas tersisa 444 perusahaan. Sumber data yang digunakan berupa data sekunder yakni Laporan Keuangan yang diterbitkan melalui website OJK.

Penelitian ini mentranskripsikan indikator dalam bentuk pertanyaan untuk memudahkan dalam menganalisis informasi Laporan Keuangan. Pertanyaan yang diajukan menunjukkan seberapa luas pemenuhan karakteristik kualitatif. Perumusan alternatif metode penilaian kualitas laporan keuangan dengan melihat karakteristik kualitatif yang menggunakan pertanyaan dari penelitian Beest et al. (2009) dan pertanyaan penilaian ARA yang secara spesifik untuk laporan keuangan saja seperti yang ada pada Lampiran 1. Peneliti menggabungkan pertanyaan secara mendetail, memberikan nilai setiap pertanyaan dan pada akhirnya memberikan bobot untuk masing-masing indikator untuk selanjutnya menjadi acuan tabel pengolahan data sehingga menjadi kesatuan.

Seluruh indikator dihitung berdasarkan pemenuhan bobot sesuai kriteria pembobotan selanjutnya setelah mendapatkan nilai akhir maka hasilnya diklasifikasikan menjadi 3 kategori besar: laporan dengan kualitas buruk (33\%), laporan dengan kualitas cukup (33\%), dan laporan dengan kualitas baik (33\%). Untuk menguji validitas hasil, maka analisis tambahan dilakukan dengan membandingkan hasil yang didapat dengan hasil penilaian rating dengan pihak lain (ARA, Majalah SWA dan Forbes).

\section{Analisis dan Pembahasan}

Dari 444 data perusahaan nilai rata-rata pemenuhan kualitas karakteristik sebesar 0,75 dari nilai penuh 1,00 (periksa Lampiran), dan hanya 29\% (sekitar 128 perusahaan) dari 444 perusahaan memiliki akumulasi nilai pemenuhan kualitas di atas 0.78 . Penerapan metode pembobotan nilai kualitas karakteristik berdasar SAK menghasilkan 5 perusahaan yang menempati rating terbaik. Metode pemeringkatan alternatif dengan menilai kualitas laporan keuangan selanjutnya diaplikasikan untuk melihat keadaan kualitas laporan keuangan di Indonesia. Hasil pemeringkatan nilai dikelompokkan menjadi 3 kategori Good (Baik), Mid (Cukup) dan Bad (Buruk).

Tabel 4.1. Persentase Nilai

\begin{tabular}{|lr|l|r|r|c|}
\hline Legend & \multicolumn{1}{l|}{ Nilai } & Jumlah & \multicolumn{1}{c|}{$\%$} & Rating \\
\hline Average & 0.75 & & & & \\
Max & 0.90 & - & 444 & $100 \%$ & \\
Min & 0.57 & & & & \\
Range & 0.11 & & & & \\
\hline Good & $0.79-$ & 0.90 & 127 & $29 \%$ & $1-95$ \\
Mid & $0.69-$ & 0.78 & 274 & $61 \%$ & $96-387$ \\
Bad & $0.57-$ & 0.68 & 43 & $10 \%$ & $388-444$ \\
\hline
\end{tabular}


Tabel 4.2. Perusahan dengan 5 Rating Terbaik Dari Hasil Penelitian

\begin{tabular}{|c|c|c|c|c|c|c|c|}
\hline $\begin{array}{c}\text { Nama } \\
\text { Perusahaan }\end{array}$ & $\mathbf{z}$ & Rank & $\begin{array}{l}\text { Listing } \\
\text { Date }\end{array}$ & Sector & Subsector & $\begin{array}{c}\text { Kepemilikan } \\
\text { Publik }\end{array}$ & Audit Publik \\
\hline $\begin{array}{l}\text { Timah } \\
\text { (Persero) } \\
\text { Tbk }\end{array}$ & 0.90 & 1.00 & 19-Oct-95 & Mining & $\begin{array}{l}\text { Metal And } \\
\text { Mineral } \\
\text { Mining }\end{array}$ & $30 \%$ to $50 \%$ & $\begin{array}{l}\text { Tanudiredja, } \\
\text { Wibisana \& } \\
\text { Rekan }\end{array}$ \\
\hline $\begin{array}{l}\text { Bank OCBC } \\
\text { NISP Tbk }\end{array}$ & 0.85 & 2.00 & 20-Oct-94 & Finance & Bank & Less than $30 \%$ & $\begin{array}{l}\text { Tanudiredja, } \\
\text { Wibisana \& } \\
\text { Rekan }\end{array}$ \\
\hline $\begin{array}{l}\text { Bank } \\
\text { Himpunan } \\
\text { Saudara } \\
1906 \text { Tbk }\end{array}$ & 0.85 & 2.00 & $\begin{array}{l}\text { 15-Dec- } \\
06\end{array}$ & Finance & Bank & $30 \%$ to $50 \%$ & $\begin{array}{l}\text { Tanudiredja, } \\
\text { Wibisana \& } \\
\text { Rekan }\end{array}$ \\
\hline $\begin{array}{l}\text { Sarana } \\
\text { Menara } \\
\text { Nusantara } \\
\text { Tbk }\end{array}$ & 0.85 & 2.00 & 8-Mar-10 & $\begin{array}{l}\text { Infrastructur } \\
\text { e, Utilities } \\
\text { and } \\
\text { Transportati } \\
\text { on }\end{array}$ & $\begin{array}{l}\text { Non } \\
\text { Building } \\
\text { Construction }\end{array}$ & Bigger $50 \%$ & $\begin{array}{l}\text { Purwantono, } \\
\text { Suherman \& } \\
\text { Surja }\end{array}$ \\
\hline $\begin{array}{l}\text { Bank } \\
\text { Mandiri } \\
\text { (Persero) } \\
\text { Tbk }\end{array}$ & 0.85 & 5.00 & 14-Jul-03 & Finance & Bank & $30 \%$ to $50 \%$ & $\begin{array}{l}\text { Tanudiredja, } \\
\text { Wibisana \& } \\
\text { Rekan }\end{array}$ \\
\hline $\begin{array}{l}\text { Bank CIMB } \\
\text { Niaga Tbk }\end{array}$ & 0.85 & 5.00 & $\begin{array}{l}29-N o v- \\
89\end{array}$ & Finance & Bank & Less than $30 \%$ & $\begin{array}{l}\text { Tanudiredja, } \\
\text { Wibisana \& } \\
\text { Rekan }\end{array}$ \\
\hline $\begin{array}{l}\text { Perusahaan } \\
\text { Gas Negara } \\
\text { (Persero) } \\
\text { Tbk }\end{array}$ & 0.85 & 5.00 & $\begin{array}{l}15-\mathrm{Dec}- \\
03\end{array}$ & $\begin{array}{l}\text { Infrastructur } \\
\text { e, Utilities } \\
\text { And } \\
\text { Transportati } \\
\text { on }\end{array}$ & Energy & $30 \%$ to $50 \%$ & $\begin{array}{l}\text { Purwantono, } \\
\text { Suherman \& } \\
\text { Surja }\end{array}$ \\
\hline $\begin{array}{l}\text { Tambang } \\
\text { Batubara } \\
\text { Bukit Asam } \\
\text { Tbk }\end{array}$ & 0.85 & 5.00 & $\begin{array}{l}23-\mathrm{Dec}- \\
02\end{array}$ & Mining & Coal Mining & Less than $30 \%$ & $\begin{array}{l}\text { Tanudiredja, } \\
\text { Wibisana \& } \\
\text { Rekan }\end{array}$ \\
\hline
\end{tabular}

\subsection{Temuan Dan Implikasi Penelitian}

(a). Temuan: Fenomena selama proses penilaian dan analisis atas hasil penelitian

Selain hasil berupa rangking rating seperti tampak pada tabel 3 di atas, penelitian juga menemukan fakta berdasar pemberian nilai per indikator pertanyaan di masing-masing perusahaan dapat dilihat sebagai berikut:

1. Sebanyak $54 \%$ perusahaan tersebut memiliki kepemilikan publik lebih kecil dari $30 \%$, sedangkan 35\% memiliki kepemilikan publik antara 30\% - 50\% sedangkan $11 \%$ sisanya dimiliki publik lebih dari 50\%.

2. Lokasi perusahaan menyebar tidak merata, $82 \%$ beroperasi dan memiliki kantor pusat di Jakarta, sedangkan 9\% di kota BODETABEK, 6\% di Surabaya dan sisanya tersebar di kota Bandung, Batam, Medan dan Makassar.

3. Dari populasi sebanyak 438 perusahaan, $41 \%$ diantaranya menggunakan jasa audit KAP dalam kategori Big Four. Sebanyak 68\% perusahaan dari total seluruh populasi mendapatkan opini wajar tanpa pengecualian dan tidak terdapat paragrap penjelas ataupun tambahan. 
4. Sebanyak $92 \%$ perusahaan dari total seluruh populasi menyampaikan pelaporan keuangannya dalam jangka waktu 1-3 bulan. Sebanyak 7\% perusahaan, mengirimkan kembali laporan keuangan dalam bentuk revisi dalam jangka waktu 1 -11 bulan sejak laporan keuangan pertama diterbitkan dan hanya 2 perusahaan atau $0.01 \%$ yang melakukan restatement laporan keuangan di tahun berikutnya (>/ 12 bulan).

5. Hanya sebesar $21.7 \%$ perusahaan dari total seluruh perusahaan menyertakan pernyataan pertanggung jawaban manajemen dengan diwakili oleh Direksi dan Komisaris, sedangkan sisanya hanya diwakili oleh satu atau dua direksi dengan keterangan sebagai Surat Pernyataan Direksi bukan Surat Pernyataan Managemen.

6. Beberapa perusahaan yang termasuk di dalamnya masuk dalam subsektor Industri Kayu, Kimia, Plastik dan Baja, dimana banyak menggunakan jargon teknis dalam laporan keuangan mudah tanpa ada penjelasan lebih lanjut.

(b). Pengamatan Hasil Penelitian: Perbedaan hasil rating dengan penelitian lain dan pola pengguna di pasar.

Penilai kualitas perusahaan di Indonesia menggunakan metode yang beragam, seperti misalnya penilai kualitas seperti Annual Report Award (ARA) yang melihat kualitas Laporan Keuangan dengan menggunakan cara penyampaian laporan tahunan dengan berdasarkan Corporate Governanace, majalah Forbes yang memberikan peringkat kualitas Perusahaan (bukan Laporan keuangan) berdasarkan ketahanan ekonomi disaat ketidakpastian global, dan majalah SWA memiliki metode lain lagi dalam menilai kualitas sebuah perusahaan (data keuangan), yakni dengan menggunakan metode Wealth Added Index (WAI) yang menggambarkan peningkatan kekayaan pemegang saham. Penilaian dengan indikator yang berbeda-beda tersebut dapat diterima karena memberikan tambahan informasi yang saling melengkapi. Peneliti kemudian membandingkan perusahaanperusahaan tersebut dalam LQ 45 periode Feb 2014 (www.idx.co.id) sebagai pilihan yang saat ini sangat umum dan sering digunakan sebagai referensi untuk melihat transaksi dan volume penjualan aktif atas saham. Perbandingan hasil rating dapat dilihat pada Lampiran 2.

Beberapa faktor yang membedakan ataupun mendukung rating hasil dari penelitian ini dengan hasil dari instansi lain adalah sebagai berikut:

1. Rating yang dihasilkan oleh ARA - OJK menunjukkan realitas penelitian atas penilaian kualitas dengan metode pemenuhan (Compliance) dan spesifik atas indikator tertentu (GCG). Hasil yang ditunjukkan tidak serta-merta perusahaan dengan kualitas GCG yang terbaik menjadi pilihan utama investor untuk membeli saham beredar dan masuk dalam LQ 45. Rating yang dihasilkan oleh majalah SWA dan Forbes, sebelum dihubungkan dengan pola pengambilan keputusan di pasar, dikategorikan sebagai penilaian kualitas informasi pada laporan keuangan yang fokus pada laba atau earning. Setelah dihubungkan dengan pola pengguna pasar secara sederhana dengan melihat pola aktif saham LQ 45, maka dapat dilihat bahwa perusahaan-perusahaan dengan laba yang baik dan juga konsisten belum tentu masuk sebagai kategori pilihan utama investor untuk dibeli sahamnya. 
2. Hasil dengan kategori Good dan Mid dalam penelitian ini ternyata menunjukkan adanya keselarasan dengan hasil yang masuk sebagai unggulan dalam kategori lain.

3. Pengguna laporan keuangan dalam hal ini investor lebih memiliki perhatian utama pada informasi keuangan yang disajikan tanpa memasukkan pertimbangan khusus apakah informasi keuangan tersebut berkualitas (dalam hal informasi berdasar SAK). Sebagai contoh investor tidak menilai lebih usaha manajemen perusahaan untuk memberikan informasi lebih cepat (tepat waktu) dibanding manajemen perusahaan pesaing.

Fenomena yang muncul tersebut menjawab bahwa reaksi pasar modal saat ini dipengaruhi oleh banyak faktor lain di luar kualitas laporan keuangan itu sendiri. Namun paling tidak dengan adanya penelitian ini yang menganalisis laporan keuangan berdasarkan karakteristik kualitatif, maka pilihan perusahaan menjadi terfokus pada perusahaan dengan informasi baik (Good) dan cukup (Mid). Dapat dilihat dalam Lampiran 3, bahwa hasil yang didapatkan atas informasi laporan keuangan dengan indikator pemenuhan karakter kualitatif seluruh perusahaan yang masuk sebagai rating di instasi lain memiliki kualitas paling tidak cukup (Mid).

Melihat temuan tersebut dapat dikatakan bahwa kualitas karakteristik Laporan Keuangan akan memiliki pengaruh positif karena fungsi akuntansi menjadi sangat penting. Pada keadaan pasar yang tidak cukup efisien, informasi lain seperti politik dan keadaan ekonomi umum bisa menjadi sangat dominan dan bias sehingga mempengaruhi para pengambil keputusan yang juga relatif naïf. Pelaku pasar juga sangat mudah menerima informasi yang dihasilkan oleh intermediari, terutama karena keragaman latar belakang dan keterbatasan mereka dalam mengolah informasi keuangan. Pilihan rating atas kualitas Laporan Keuangan akan menunjukkan kualitas laporan keuangan tersebut bisa diperbandingkan. Peneliti melihat hasil dari penelitian ini dapat menjadi nilai tambah dan saling melengkapi dengan informasi kualitas lain seperti kualitas laba, ketahanan ekonomi dan juga pola pengguna di pasar modal.

\section{Kesimpulan, Keterbatasan, dan Saran}

\subsection{Kesimpulan}

Beberapa kesimpulan yang dapat ditarik sebagai berikut:

1. Penilaian kualitas laporan keuangan dengan melihat karakteristik kualitatif ini sudah secara cukup bisa menunjukkan seberapa luas pemenuhan kualitas karakteristik laporan keuangan di Indonesia. Peratingan yang dihasilkan dalam penelitian ini mampu menjadi alternatif pemeringkatan berbasis kualitas karakteristik kualitatif Laporan Keuangan Perusahaan yang terdaftar di Bursa Efek Indonesia.

2. Hasil penelitian mengenai luas pemenuhan kualitas karakteristik laporan keuangan ternyata tidak serta merta menjadi preferensi utama investor karena sudah ada hasil rating dari intermediari lainnya. Analisis perbandingan hasil rating yang sudah ada dari perspektif lain 
tersebut menunjukkan bahwa masing-masing produk rating dipandang sebagai alternatif yang saling menunjang karena bersifat komplimentari (melengkapi) dan juga subsidiari (menggambarkan sebagian yang lebih spesifik tergantung pada preferensi pemegang saham).

3. Hasil yang didapat menunjukkan bahwa, perusahaan dengan karakteristik kualitatif yang baik (Good) dan cukup (Mid) juga memiliki penilaian yang sejalan dengan analisis lainnya. Laporan Keuangan yang memberikan informasi berkualitas, bisa memberikan rasa aman bagi pengguna.

Secara keseluruhan peneliti melihat analisis dengan menggunakan karakteristik kualitatif dalam laporan keuangan mampu memberikan metode alternatif pengukuran serta nilai tambah informasi yang sederhana, mudah dicerna tetapi memiliki manfaat tersendiri bagi pengambil keputusan dari beragam latar belakang. Hasil penelitian ini dapat berguna untuk studi yang sama di masa depan dengan mempertimbangkan beberapa keterbatasan penelitian ini.

\subsection{Keterbatasan}

Keterbatasan penelitian adalah:

1. Penelitian ini belum dapat membuktikan bahwa metode penilaian kualitas Laporan Keuangan ini dapat menjadi pilihan utama. Diperlukan uji tambahan agar bisa diterima dengan baik.

2. Fakta bahwa periode dipelajari hanya satu tahun.

3. Populasi perusahaan hanya di Indonesia, penelitian akan datang dapat menggunakan perusahaan dari negara lain.

4. Tidak ada kualifikasi pendukung pada pentingnya bobot per indikator. Peneliti kesulitan untuk menentukan bobot pengukuran pada setiap variabel karena standar yang ada saat ini memberikan kebebasan berasumsi (SFAC 2010).

\subsection{Saran}

Dengan memperhatikan simpulan dan keterbatasan yang ada maka disarankan untuk:

1. Penelitian selanjutnya diharapkan dapat melakukan pendekatan observasi perilaku pengguna informasi rating, karena metode ini mempunyai hasil pemahaman yang lebih luas sehingga dapat lebih jelas menangkap fenomena penggunaan rating dalam pengambilan keputusan.

2. Pengujian dengan pengamatan yang lebih lama diharapkan untuk memperoleh pandangan yang lebih luas dan memberikan hasil yang lebih baik. Di samping itu, penelitian berikutnya dapat menguji sampel penelitian yang diperoleh berdasarkan periode dan populasi yang sama untuk mengetahui apakah ada perbedaan hasil jika analisis dilakukan oleh pihak yang berbeda. 
3. Penelitian selanjutnya diharapkan dapat memperluas obyek penelitian dengan negara lain sehingga mampu mengeneralisasi kesimpulan penelitian secara lebih luas dan menguji bahwa metode penilaian ini bisa digeneralisasi, dan memberikan dampak motivasi bagi perusahaan di Indonesia untuk lebih baik lagi.

4. Peneliti selanjutnya bisa menambahkan beberapa indikator untuk melengkapi apa yang sudah diteliti kali ini, misalnya saja dengan menggabungkan indikator karakteristik kualitatif dengan indikator GCG, ketahanan ekonomi dan keberlangsungan usaha yang dinilai dari kinerja keuangan.

\section{Daftar Pustaka}

Akerlof, G. A. 1970. The market for" lemons": Quality uncertainty and the market mechanism. The quarterly journal of economics, 488-500.

Ball, R., \& P. Brown. 1968. An empirical evaluation of accounting income numbers. Journal of accounting research, 159-178.

Barnard, C. I. 1968. The functions of the executive (Vol. 11): Harvard university press.

Barth, M. E., W.R. Landsman., \& M.H. Lang. 2008. International accounting standards and accounting quality. Journal of accounting research, 46(3), 467-498.

Bazerman, M., \& D.A. Moore. 2012. Judgment in managerial decision making.

Beaver, W. H. 1968. The information content of annual earnings announcements. Journal of accounting research, 67-92.

Beest, F. V., Braam, G., \& Boelens, S. 2009. Quality of Financial Reporting: measuring qualitative characteristics. Nijmegen Center for Economics (NiCE). Working Paper, 09-108.

Botosan, C. A. 2006. Disclosure and the cost of capital: what do we know? Accounting and business research, 36(sup1), 31-40.

Cohen, D. A., \& T.Z. Lys. 2003. A note on analysts' earnings forecast errors distribution. Journal of accounting and economics, 36(1-3), 147-164. doi: http://dx.doi.org/10.1016/j.jacceco.2003.11.002

2006. Weighing the evidence on the relation between external corporate financing activities, accruals and stock returns. Journal of accounting and economics, 42(1-2), 87-105. doi: http://dx.doi.org/10.1016/j.jacceco.2006.04.006

Cohen, D. A., \& P. Zarowin. 2010. Accrual-based and real earnings management activities around seasoned equity offerings. Journal of accounting and economics, 50(1), 2-19. doi: http://dx.doi.org/10.1016/j.jacceco.2010.01.002

Cooke, T. E. 1992. The Impact of Size, Stock Market Listing and Industry Type on Disclosure in the Annual Reports of Japanese Listed Corporations. Accounting and business research, 22(87), 229.

Dechow, P. M., \& I.D. Dichev. 2002. The quality of accruals and earnings: The role of accrual estimation errors. The Accounting Review, 77(s-1), 35-59.

Epstein, B. J., \& E.K. Jermakowicz. 2010. WILEY Interpretation and Application of International Financial Reporting Standards 2010: John Wiley \& Sons.

Foster, G. 1978. Financial Statement Analysis, 2/e: India: Pearson Education.

Francis, J., LaFond, R., Olsson, P. M., \& Schipper, K. 2004. Costs of equity and earnings attributes. The Accounting Review, 79(4), 967-1010. 
Healy, P. M., \& K.G. Palepu. 1993. The effect of firms' financial disclosure strategies on stock prices. Accounting Horizons, 7, 1-1.

2001. Information asymmetry, corporate disclosure, and the capital markets: A review of the empirical disclosure literature. Journal of accounting and economics, 31(1), 405440.

Holthausen, R. W., \& R.L. Watts. 2001. The relevance of the value-relevance literature for financial accounting standard setting. Journal of accounting and economics, 31(1), 3-75.

IASB. 2008. An improved Conceptual Framework for Financial Reporting-Chapter 1, The Objective of Financial Reporting; Chapter 2, Qualitative Characteristics and Constraints of Decision-useful Financial Reporting Information (Vol. Draft Exposure): London, IASC Foundation Publications Department (May 2008)“... an assertion, proposition, statement or belief, is true if, and only if, it corresponds to the facts.

IASB. 2010. The Conceptual Framework for Financial Reporting: IFRS Foundation London.

Jensen, M. C., \& W.H. Meckling. 1979. Theory of the firm: Managerial behavior, agency costs, and ownership structure: Springer.

Kieso, D. E., J.J. Weygandt., \& T.D. Warfield. 2010. Intermediate accounting: IFRS edition (Vol. 2): John Wiley \& Sons.

Leuz, C., \& R.E. Verrecchia. 2000. The Economic Consequences of Increased Disclosure (Digest Summary). Journal of accounting research, 38, 91-124No.

McDaniel, L., R.D. Martin., L.A. Maines., \& M.E. Peecher. 2002. Evaluating Financial Reporting Quality: The Effects of Financial Expertise vs. Financial Literacy / DISCUSSION OF Evaluating Financial Reporting Quality: The Effects of Financial Expertise vs. Financial Literacy. The Accounting Review, 77, 139-167,169-173.

Nindita, C., \& S.V. Siregar. 2012. Analisis Pengaruh Ukuran Kantor Akuntan Publik Terhadap Kualitas Audit di Indonesia. Jurnal Akuntansi dan Keuangan, 14(2), 91-104.

Obaidat, A. N. 2007. Accounting Information Qualitative Characteristics Gap: Evidence from Jordan. International Management Review, 3(2), 26-32.

OJK. 2014. KRITERIA ANNUAL REPORT AWARD 2014*). Retrieved 29 April 2014

Penman, S. H. 2007. Financial reporting quality: is fair value a plus or a minus? Accounting and business research, 37(sup1), 33-44.

Penman, S. H., \& X.J. Zhang. 2002. Accounting conservatism, the quality of earnings, and stock returns. The Accounting Review, 77(2), 237-264.

SAK. 2012. Standar Akuntansi Keuangan. Indonesia: Ikatan Akuntan Indonesia.

Scott, W. R. 2012. Financial accounting theory (Vol. 6): Prentice Hall Upper Saddle River, NJ.

Sekaran, U. 2003. Research methods for business: A skill building approach (Vol. 3): John Wiley \& Sons.

SFAC No 8. 2010. SFAC No 8 FASB (Ed.)

Spence, M. 1973. Job market signaling. The quarterly journal of economics, 355-374.

Street, D. L., \& S.J. Gray. 2002. Factors influencing the extent of corporate compliance with International Accounting Standards: summary of a research monograph. Journal of International Accounting, Auditing and Taxation, 11(1), 51-76.

Subroto, B. 2003. Faktor-faktor yang mempengaruhi kepatuhan kepada ketentuan pengungkapan wajib oleh perusahaan-perusahaan publik dan implikasinya terhadap kepercayaan investor di pasar modal. Universitas Gadjah Mada.

Tsalavoutas, I., L. Evans., \& M. Smith. 2010. Comparison of two methods for measuring compliance with IFRS mandatory disclosure requirements. Journal of Applied Accounting Research, 11 (3), 213228. doi: http://dx.doi.org/10.1108/09675421011088143 
Verrecchia, R. E. 2001. Essays on disclosure. Journal of accounting and economics, 32(1), 97-180.

Watts, R. L., \& J.L. Zimmerman. 1983. Agency problems, auditing, and the theory of the firm: Some evidence. Journal of law and Economics, 613-633. 131-156.

Yin, R. K. 2011. Qualitative research from start to finish: Guilford Press.

www.forbesindonesia.com.

www.idx.co.id.

www.swa.co.id. 
Lampiran 1: Pembagian point perhitungan per pertanyaan dan Simulasi perhitungan bobot

\begin{tabular}{|c|c|c|c|c|c|c|}
\hline & Indikator & & ertanyaan yang di & gunakan untuk mewakili Indikator & $\begin{array}{l}\text { Literature } \\
\text { sebelumnya }\end{array}$ & $\begin{array}{l}\text { Maks } \\
\text { Point }\end{array}$ \\
\hline 1 & Predictive Value & 1 & $\begin{array}{l}\text { Sejauh mana } \\
\text { perusahaan } \\
\text { menggunakan } \\
\text { nilai wajar bukan } \\
\text { biaya historis }\end{array}$ & $\begin{array}{l}1=\text { Seluruh dalam biaya historis } \\
2=75 \% \text { menggunakan biaya } \\
\text { historis } \\
3=\text { Imbang menggunakan nilai } \\
\text { kini(FV)/ biaya historis } \\
4=75 \% \text { menggunakan nilai kini } \\
5=\text { Seluruh dalam nilai kini }\end{array}$ & $\begin{array}{l}\text { e.g. Schipper and } \\
\text { Vincent, 2003; } \\
\text { McDaniel et al., } \\
\text { 2002; } \\
\text { Barth et al., 2001; } \\
\text { Schipper, } 2003\end{array}$ & 2.97 \\
\hline & & 2 & $\begin{array}{l}\text { Ikhtisar } \\
\text { Kebijakan } \\
\text { Akuntansi }\end{array}$ & $\begin{array}{l}\text { Meliputi sekurang-kurangnya: } \\
\text { 4. Imbalan kerja; dan } \\
\text { 5. Instrumen Keuangan. }\end{array}$ & $\begin{array}{l}\text { Peraturan } \\
\text { Bapepam Nomor } \\
\text { VIII.G.7 Kep- } \\
\text { 347/BL/2012, \& } \\
\text { Peraturan } \\
\text { Bapepam Nomor } \\
\text { X.K.6 Kep- } \\
\text { 431/BL/2012 } \\
\text { PSAK } 01\end{array}$ & 2.97 \\
\hline & & 3 & $\begin{array}{l}\text { Pengungkapan } \\
\text { yang } \\
\text { berhubungan } \\
\text { dengan } \\
\text { perpajakan }\end{array}$ & $\begin{array}{l}\text { Hal-hal yang harus diungkapkan: } \\
\text { 1. Rekonsiliasi fiskal dan } \\
\text { perhitungan beban pajak kini; } \\
\text { 3. Pernyataan bahwa Laba Kena } \\
\text { Pajak (LKP) hasil rekonsiliasi } \\
\text { dijadikan dasar dalam pengisian } \\
\text { SPT Tahunan PPh Badan; }\end{array}$ & $\begin{array}{l}\text { Peraturan } \\
\text { Bapepam Nomor } \\
\text { VIII.G.7 Kep- } \\
\text { 347/BL/2012, \& } \\
\text { Peraturan } \\
\text { Bapepam Nomor } \\
\text { X.K.6 Kep- } \\
\text { 431/BL/2012 } \\
\text { PSAK 46 } \\
\end{array}$ & 2.97 \\
\hline & & 4 & $\begin{array}{l}\text { Pengungkapan } \\
\text { yang } \\
\text { berhubungan } \\
\text { dengan aset } \\
\text { tetap }\end{array}$ & $\begin{array}{l}\text { Hal-hal yang harus diungkapkan: } \\
\text { 3. Metode dan asumsi signifikan } \\
\text { yang digunakan dalam } \\
\text { mengestimasi nilai wajar aset } \\
\text { tetap (untuk model revaluasi) atau } \\
\text { pengungkapan nilai wajar aset } \\
\text { tetap (untuk model biaya); dan }\end{array}$ & $\begin{array}{l}\text { Peraturan } \\
\text { Bapepam Nomor } \\
\text { VIII.G.7 Kep- } \\
\text { 347/BL/2012, \& } \\
\text { Peraturan } \\
\text { Bapepam Nomor } \\
\text { X.K.6 Kep- } \\
\text { 431/BL/2012 } \\
\text { PSAK 16 }\end{array}$ & 2.97 \\
\hline & & 5 & $\begin{array}{l}\text { Pengungkapan } \\
\text { yang } \\
\text { berhubungan } \\
\text { dengan segmen } \\
\text { operasi }\end{array}$ & $\begin{array}{l}\text { Hal-hal yang harus diungkapkan: } \\
\text { 1. Informasi umum yang meliputi } \\
\text { faktor-faktor yang digunakan untuk } \\
\text { mengidentifikasi segmen yang } \\
\text { dilaporkan; }\end{array}$ & $\begin{array}{l}\text { Peraturan } \\
\text { Bapepam Nomor } \\
\text { VIII.G.7 Kep- } \\
\text { 347/BL/2012, \& } \\
\text { Peraturan } \\
\text { Bapepam Nomor } \\
\text { X.K.6 Kep- } \\
\text { 431/BL/2012 } \\
\text { PSAK 5 }\end{array}$ & 2.97 \\
\hline & & 6 & $\begin{array}{l}\text { Pengungkapan } \\
\text { yang } \\
\text { berhubungan } \\
\text { dengan } \\
\text { Instrumen } \\
\text { Keuangan }\end{array}$ & $\begin{array}{l}\text { Hal-hal yang harus diungkapkan: } \\
5 \text {. Analisis risiko yang terkait } \\
\text { dengan instrumen keuangan } \\
\text { secara kuantitatif. }\end{array}$ & $\begin{array}{l}\text { Peraturan } \\
\text { Bapepam Nomor } \\
\text { VIII.G.7 Kep- } \\
\text { 347/BL/2012, \& } \\
\text { Peraturan } \\
\text { Bapepam Nomor } \\
\text { X.K.6 Kep- } \\
\text { 431/BL/2012 } \\
\text { PSAK 50, 55 dan } \\
60\end{array}$ & 2.97 \\
\hline 2 & $\begin{array}{l}\text { Confirmatory } \\
\text { Value }\end{array}$ & 1 & $\begin{array}{l}\text { Laporan Arus } \\
\text { Kas }\end{array}$ & $\begin{array}{l}\text { Memenuhi ketentuan sebagai } \\
\text { berikut: } \\
\text { 4. Pengungkapan transaksi non } \\
\text { kas harus dicantumkan dalam } \\
\text { catatan atas laporan keuangan. }\end{array}$ & $\begin{array}{l}\text { Peraturan } \\
\text { Bapepam Nomor } \\
\text { VIII.G.7 Kep- } \\
\text { 347/BL/2012, \& } \\
\text { Peraturan } \\
\text { Bapepam Nomor } \\
\end{array}$ & 2.97 \\
\hline
\end{tabular}




\begin{tabular}{|c|c|c|c|c|c|c|}
\hline \multicolumn{2}{|c|}{ Indikator } & \multicolumn{3}{|c|}{ Pertanyaan yang digunakan untuk mewakili Indikator } & \multirow{2}{*}{$\begin{array}{l}\begin{array}{r}\text { Literature } \\
\text { sebelumnya }\end{array} \\
\text { X.K.6 Kep- } \\
\text { 431/BL/2012 } \\
\text { PSAK } 2\end{array}$} & \multirow[t]{2}{*}{$\begin{array}{l}\text { Maks } \\
\text { Point }\end{array}$} \\
\hline & & & & & & \\
\hline & & 2 & $\begin{array}{l}\text { Pengungkapan } \\
\text { yang } \\
\text { berhubungan } \\
\text { dengan } \\
\text { perpajakan }\end{array}$ & $\begin{array}{l}\text { Hal-hal yang harus diungkapkan: } \\
\text { 2. Penjelasan hubungan antara } \\
\text { beban (penghasilan) pajak dan } \\
\text { laba akuntansi; } \\
\text { 4. Rincian aset dan liabilitas pajak } \\
\text { tangguhan yang diakui pada } \\
\text { laporan posisi keuangan untuk } \\
\text { setiap periode penyajian, dan } \\
\text { jumlah beban (penghasilan) pajak } \\
\text { tangguhan yang diakui pada } \\
\text { laporan laba rugi apabila jumlah } \\
\text { tersebut tidak terlihat dari jumlah } \\
\text { aset atau liabilitas pajak } \\
\text { tangguhan yang diakui pada } \\
\text { laporan posisi keuangan; dan }\end{array}$ & $\begin{array}{l}\text { Peraturan } \\
\text { Bapepam Nomor } \\
\text { VIII.G.7 Kep- } \\
\text { 347/BL/2012, \& } \\
\text { Peraturan } \\
\text { Bapepam Nomor } \\
\text { X.K.6 Kep- } \\
\text { 431/BL/2012 } \\
\text { PSAK } 46\end{array}$ & 2.97 \\
\hline & & 3 & $\begin{array}{l}\text { Pengungkapan } \\
\text { yang } \\
\text { berhubungan } \\
\text { dengan segmen } \\
\text { operasi }\end{array}$ & $\begin{array}{l}\text { Hal-hal yang harus diungkapkan: } \\
\text { 3. Rekonsiliasi dari total } \\
\text { pendapatan segmen, laba rugi } \\
\text { segmen yang dilaporkan, aset } \\
\text { segmen, liabilitas segmen, dan } \\
\text { unsur material segmen lainnya } \\
\text { terhadap jumlah terkait dalam } \\
\text { entitas; dan }\end{array}$ & $\begin{array}{l}\text { Peraturan } \\
\text { Bapepam Nomor } \\
\text { VIII.G.7 Kep- } \\
\text { 347/BL/2012, \& } \\
\text { Peraturan } \\
\text { Bapepam Nomor } \\
\text { X.K.6 Kep- } \\
\text { 431/BL/2012 } \\
\text { PSAK 5 }\end{array}$ & 2.97 \\
\hline & & 4 & $\begin{array}{l}\text { Pengungkapan } \\
\text { yang } \\
\text { berhubungan } \\
\text { dengan } \\
\text { Instrumen } \\
\text { Keuangan }\end{array}$ & $\begin{array}{l}\text { Hal-hal yang harus diungkapkan: } \\
\text { 4. Penjelasan risiko yang terkait } \\
\text { dengan instrumen keuangan: } \\
\text { risiko pasar, risiko kredit dan risiko } \\
\text { likuiditas; dan }\end{array}$ & $\begin{array}{l}\text { Peraturan } \\
\text { Bapepam Nomor } \\
\text { VIII.G.7 Kep- } \\
\text { 347/BL/2012, \& } \\
\text { Peraturan } \\
\text { Bapepam Nomor } \\
\text { X.K.6 Kep- } \\
\text { 431/BL/2012 } \\
\text { PSAK 50, 55 dan } \\
60\end{array}$ & 2.97 \\
\hline 3 & Completeness & 1 & $\begin{array}{l}\text { Laporan } \\
\text { keuangan yang } \\
\text { lengkap }\end{array}$ & $\begin{array}{l}\text { Memuat secara lengkap unsur- } \\
\text { unsur laporan keuangan:1. } \\
\text { Laporan posisi keuangan } \\
\text { (neraca);2. Laporan laba rugi } \\
\text { komprehensif;3. Laporan } \\
\text { perubahan ekuitas;4. Laporan arus } \\
\text { kas;5. Catatan atas laporan } \\
\text { keuangan; dan6. Laporan posisi } \\
\text { keuangan pada awal periode } \\
\text { komparatif yang disajikan ketika } \\
\text { entitas menerapkan suatu } \\
\text { kebijakan akuntansi secara } \\
\text { retrospektif atau membuat } \\
\text { penyajian kembali pos-pos laporan } \\
\text { keuangan, atau ketika entitas } \\
\text { mereklasifikasi pos-pos dalam } \\
\text { laporan keuangannya (jika } \\
\text { relevan). }\end{array}$ & $\begin{array}{l}\text { Peraturan } \\
\text { Bapepam Nomor } \\
\text { VIII.G.7 Kep- } \\
347 / \text { BL/2012, \& } \\
\text { Peraturan } \\
\text { Bapepam Nomor } \\
\text { X.K.6 Kep- } \\
\text { 431/BL/2012PSAK } \\
1\end{array}$ & 2.97 \\
\hline
\end{tabular}




\begin{tabular}{|c|c|c|c|c|c|c|}
\hline \multicolumn{2}{|c|}{ Indikator } & \multicolumn{3}{|c|}{ Pertanyaan yang digunakan untuk mewakili Indikator } & \multirow{2}{*}{\begin{tabular}{l}
\multicolumn{1}{c}{$\begin{array}{c}\text { Literature } \\
\text { sebelumnya }\end{array}$} \\
e.g. Dechow et al., \\
1996; McMullen, \\
1996; \\
Beasley, 1996; \\
Razaee, \\
2003; Cohen et al., \\
2004; Sloan, 2001
\end{tabular}} & \multirow{2}{*}{$\begin{array}{r}\text { Maks } \\
\text { Point } \\
2.97\end{array}$} \\
\hline$\overline{4}$ & \multirow[t]{4}{*}{ Neutrality } & 1 & $\begin{array}{l}\text { Sejauh mana } \\
\text { perusahaan, } \\
\text { dalam } \\
\text { pembahasan } \\
\text { catatan } \\
\text { keuangan, } \\
\text { menyorot } \\
\text { peristiwa positif } \\
\text { serta peristiwa } \\
\text { negatif? }\end{array}$ & $\begin{array}{l}\text { = Peristiwa negative tidak } \\
\text { disinggung sama sekali (hanya } \\
\text { terlihat ketika subsequent) } \\
2=\text { Menekankan pada peristiwa } \\
\text { positif } \\
3=\text { Menekankan pada peristiwa } \\
\text { positif, tetapi peristiwa negatif } \\
\text { disebutkan; tidak ada kejadian } \\
\text { negatif terjadi } \\
4=\text { Hanya catatan atas peristiwa } \\
\text { negative dan positif } \\
5=\text { Catatan dan penjelasan } \\
\text { pengaruh atas peristiwa negative } \\
\text { dan positif }\end{array}$ & & \\
\hline & & 2 & $\begin{array}{l}\text { Ikhtisar } \\
\text { Kebijakan } \\
\text { Akuntansi }\end{array}$ & $\begin{array}{l}\text { Meliputi sekurang-kurangnya: } \\
\text { 1. Pernyataan kepatuhan terhadap } \\
\text { SAK; }\end{array}$ & $\begin{array}{l}\text { Peraturan } \\
\text { Bapepam Nomor } \\
\text { VIII.G.7 Kep- } \\
\text { 347/BL/2012, \& } \\
\text { Peraturan } \\
\text { Bapepam Nomor } \\
\text { X.K.6 Kep- } \\
\text { 431/BL/2012 }\end{array}$ & 2.97 \\
\hline & & 3 & $\begin{array}{l}\text { Pengungkapan } \\
\text { transaksi pihak } \\
\text { berelasi }\end{array}$ & $\begin{array}{l}\text { Hal-hal yang diungkapkan antara } \\
\text { lain: } \\
\text { 1. Nama pihak berelasi, serta sifat } \\
\text { dan hubungan dengan pihak } \\
\text { berelasi; } \\
\text { 2. Nilai transaksi beserta } \\
\text { persentasenya terhadap total } \\
\text { pendapatan dan beban terkait; dan } \\
\text { 3. Jumlah saldo beserta } \\
\text { persentasenya terhadap total aset } \\
\text { atau liabilitas. }\end{array}$ & $\begin{array}{l}\text { Peraturan } \\
\text { Bapepam Nomor } \\
\text { VIII.G.7 Kep- } \\
\text { 347/BL/2012, \& } \\
\text { Peraturan } \\
\text { Bapepam Nomor } \\
\text { X.K.6 Kep- } \\
\text { 431/BL/2012 } \\
\text { PSAK } 7\end{array}$ & 2.97 \\
\hline & & 4 & $\begin{array}{l}\text { Pengungkapan } \\
\text { yang } \\
\text { berhubungan } \\
\text { dengan } \\
\text { perpajakan }\end{array}$ & $\begin{array}{l}\text { Hal-hal yang harus diungkapkan: } \\
\text { 5. Pengungkapan ada atau tidak } \\
\text { ada sengketa pajak. }\end{array}$ & $\begin{array}{l}\text { Peraturan } \\
\text { Bapepam Nomor } \\
\text { VIII.G.7 Kep- } \\
\text { 347/BL/2012, \& } \\
\text { Peraturan } \\
\text { Bapepam Nomor } \\
\text { X.K.6 Kep- } \\
\text { 431/BL/2012 } \\
\text { PSAK 46 }\end{array}$ & 2.97 \\
\hline \multirow[t]{2}{*}{5} & \multirow[t]{2}{*}{ Free from error } & 1 & $\begin{array}{l}\text { Jenis opini yang } \\
\text { diberikan oleh } \\
\text { auditor? }\end{array}$ & $\begin{array}{l}1=\text { Adverse opinion } \\
2=\text { Disclaimer of opinion } \\
3=\text { Qualified opinion } \\
4=\text { Unqualified opinion: Financial } \\
\text { figures } \\
5=\text { Unqualified opinion: Financial } \\
\text { figures + internal control }\end{array}$ & $\begin{array}{l}\text { e.g. Maines and } \\
\text { Wahlen, 2006; } \\
\text { Gaeremynck and } \\
\text { Willekens, 2003; } \\
\text { Kim } \\
\text { et al., 2007; } \\
\text { Willekens, } \\
2008\end{array}$ & 2.97 \\
\hline & & 2 & $\begin{array}{l}\text { Opini auditor } \\
\text { independen atas } \\
\text { laporan } \\
\text { keuangan }\end{array}$ & & $\begin{array}{l}\text { Peraturan } \\
\text { Bapepam Nomor } \\
\text { VIII.G.7 Kep- } \\
\text { 347/BL/2012, \& } \\
\text { Peraturan } \\
\text { Bapepam Nomor } \\
\text { X.K.6 Kep- } \\
\text { 431/BL/2012 }\end{array}$ & 2.97 \\
\hline
\end{tabular}




\begin{tabular}{|c|c|c|c|c|c|c|}
\hline \multicolumn{2}{|c|}{ Indikator } & \multicolumn{3}{|c|}{ Pertanyaan yang digunakan untuk mewakili Indikator } & \multirow{2}{*}{$\begin{array}{l}\quad \begin{array}{c}\multicolumn{1}{c}{\text { Literature }} \\
\text { sebelumnya }\end{array} \\
\text { e.g. Schipper and } \\
\text { Vincent, 2003; } \\
\text { Jonas } \\
\text { and Blanchet, } 2000\end{array}$} & \multirow{2}{*}{$\begin{array}{r}\text { Maks } \\
\text { Point } \\
2.97\end{array}$} \\
\hline \multirow[t]{5}{*}{6} & \multirow[t]{5}{*}{ Compariablity } & 1 & $\begin{array}{l}\text { Sejauh mana } \\
\text { catatan revisi } \\
\text { estimasi } \\
\text { akuntansi dan } \\
\text { penilaian } \\
\text { menjelaskan } \\
\text { implikasi dari } \\
\text { revisi? }\end{array}$ & $\begin{array}{l}1=\text { Ada revisi tapi tidak ada } \\
\text { catatan } \\
2=\text { Ada revisi dengan catatan } \\
\text { yang minimal } \\
3=\text { Tidak ada revisi, notes jelas } \\
4=\text { Notes jelas + pengaruh } \\
\text { terhadap kejadian lalu } \\
5=\text { Penjelasan sangat jelas }\end{array}$ & & \\
\hline & & 2 & $\begin{array}{l}\text { Sampai sejauh } \\
\text { mana } \\
\text { perusahaan } \\
\text { menyesuaikan } \\
\text { angka periode } \\
\text { akuntansi } \\
\text { sebelumnya, } \\
\text { untuk efek dari } \\
\text { pelaksanaan } \\
\text { perubahan } \\
\text { kebijakan } \\
\text { akuntansi atau } \\
\text { revisi estimasi } \\
\text { akuntansi? }\end{array}$ & $\begin{array}{l}1=\text { Tidak ada penyesuaian2 }= \\
\text { Menjelaskan perubahan atas } \\
\text { penyesuaian (naratif) } 3= \\
\text { Perubahan hanya di tahun } \\
\text { berjalan (satu tahun) } 4=2 \text { years } 5 \\
=>2 \text { years + catatan }\end{array}$ & $\begin{array}{l}\text { e.g. Cole et al., } \\
\text { 2007Jonas and } \\
\text { Blanchet,2000 }\end{array}$ & 2.97 \\
\hline & & 3 & $\begin{array}{l}\text { Perbandingan } \\
\text { tingkat } \\
\text { profitabilitas }\end{array}$ & $\begin{array}{l}\text { Perbandingan kinerja/laba (rugi) } \\
\text { tahun berjalan dengan tahun } \\
\text { sebelumnya. }\end{array}$ & $\begin{array}{l}\text { Peraturan } \\
\text { Bapepam Nomor } \\
\text { VIII.G.7 Kep- } \\
\text { 347/BL/2012, \& } \\
\text { Peraturan } \\
\text { Bapepam Nomor } \\
\text { X.K.6 Kep- } \\
\text { 431/BL/2012 } \\
\text { PSAK 56 }\end{array}$ & 2.97 \\
\hline & & 4 & $\begin{array}{l}\text { Laporan Arus } \\
\text { Kas }\end{array}$ & $\begin{array}{l}\text { Memenuhi ketentuan sebagai } \\
\text { berikut: } \\
\text { 1. Pengelompokan dalam tiga } \\
\text { kategori aktivitas: operasi, } \\
\text { investasi, dan pendanaan; } \\
\text { 3. Pemisahan penyajian antara } \\
\text { penerimaan kas dan atau } \\
\text { pengeluaran kas selama tahun } \\
\text { berjalan pada aktivitas operasi, } \\
\text { investasi dan pendanaan; dan }\end{array}$ & $\begin{array}{l}\text { Peraturan } \\
\text { Bapepam Nomor } \\
\text { VIII.G.7 Kep- } \\
\text { 347/BL/2012, \& } \\
\text { Peraturan } \\
\text { Bapepam Nomor } \\
\text { X.K.6 Kep- } \\
\text { 431/BL/2012 } \\
\text { PSAK } 2\end{array}$ & 2.97 \\
\hline & & 5 & $\begin{array}{l}\text { Pengungkapan } \\
\text { yang } \\
\text { berhubungan } \\
\text { dengan } \\
\text { Instrumen } \\
\text { Keuangan }\end{array}$ & $\begin{array}{l}\text { Hal-hal yang harus diungkapkan: } \\
\text { 1. Rincian instrumen keuangan } \\
\text { yang dimiliki berdasarkan } \\
\text { klasifikasinya; }\end{array}$ & $\begin{array}{l}\text { Peraturan } \\
\text { Bapepam Nomor } \\
\text { VIII.G.7 Kep- } \\
\text { 347/BL/2012, \& } \\
\text { Peraturan } \\
\text { Bapepam Nomor } \\
\text { X.K.6 Kep- } \\
\text { 431/BL/2012 } \\
\text { PSAK 50, 55 dan } \\
60\end{array}$ & 2.97 \\
\hline 7 & Veriabili-ty & 1 & $\begin{array}{l}\text { Sejauh mana } \\
\text { argumen yang } \\
\text { valid disediakan } \\
\text { untuk } \\
\text { mendukung } \\
\text { keputusan untuk } \\
\text { asumsi dan } \\
\text { perkiraan } \\
\text { tertentu dalam }\end{array}$ & $\begin{array}{l}1 \text { = Hanya menyampaikan } \\
\text { estimasi yang dibuat } \\
2=\text { Ada narasi penjelasan singkat } \\
3=\text { Penjelasan spesifik } \\
\text { menjelaskan estimasi } \\
4=\text { Penjelasan spesifik termasuk } \\
\text { rumus yang digunakan. } \\
5=\text { Komprehensive pilihan yang } \\
\text { ada atas estimasi yang dibuat }\end{array}$ & $\begin{array}{l}\text { e.g. Jonas and } \\
\text { Blanchet, } \\
\text { 2000; Maines and } \\
\text { Wahlen, } 2004\end{array}$ & 2.97 \\
\hline
\end{tabular}




\begin{tabular}{|c|c|c|c|c|c|}
\hline Indikator & \multicolumn{3}{|c|}{ Pertanyaan yang digunakan untuk mewakili Indikator } & \multirow[t]{2}{*}{$\begin{array}{c}\text { Literature } \\
\text { sebelumnya } \\
\end{array}$} & \multirow[t]{2}{*}{$\begin{array}{l}\text { Maks } \\
\text { Point }\end{array}$} \\
\hline & & $\begin{array}{l}\text { laporan } \\
\text { tahunan? }\end{array}$ & & & \\
\hline & 2 & $\begin{array}{l}\text { Sejauh mana } \\
\text { perusahaan } \\
\text { mendasarkan } \\
\text { pilihan untuk } \\
\text { prinsip } \\
\text { akuntansi } \\
\text { tertentu } \\
\text { pada argumen } \\
\text { yang valid? }\end{array}$ & $\begin{array}{l}1=\text { Ada Perubahan dan tidak } \\
\text { dijelaskan } \\
2=\text { Dijelaskan secara minimal } \\
3=\text { Dijelaskan kenapa berubah } \\
4=\text { Dijelaskan kenapa berubah }+ \\
\text { konsekuensi } \\
5=\text { Tidak ada perubahan dan } \\
\text { disertakan dalam narasi }\end{array}$ & $\begin{array}{l}\text { e.g. Jonas and } \\
\text { Blanchet, } \\
\text { 2000; Maines and } \\
\text { Wahlen, } 2004\end{array}$ & 2.97 \\
\hline & 3 & $\begin{array}{l}\text { Surat } \\
\text { Pernyataan } \\
\text { Direksi dan/atau } \\
\text { Dewan } \\
\text { Komisaris } \\
\text { tentang } \\
\text { Tanggung } \\
\text { Jawab atas } \\
\text { Laporan } \\
\text { Keuangan }\end{array}$ & $\begin{array}{l}\text { Kesesuaian dengan peraturan } \\
\text { terkait tentang Tanggung Jawab } \\
\text { atas Laporan Keuangan. } \\
\text { Disertakan dalam pernyataan } \\
\text { bermaterai }\end{array}$ & $\begin{array}{l}\text { Peraturan } \\
\text { Bapepam Nomor } \\
\text { VIII.G.7 Kep- } \\
\text { 347/BL/2012, \& } \\
\text { Peraturan } \\
\text { Bapepam Nomor } \\
\text { X.K.6 Kep- } \\
\text { 431/BL/2012 }\end{array}$ & 2.97 \\
\hline & 4 & $\begin{array}{l}\text { Deskripsi } \\
\text { Auditor } \\
\text { Independen di } \\
\text { Opini }\end{array}$ & Klasifikasi KAP dan auditor & $\begin{array}{l}\text { Peraturan } \\
\text { Bapepam Nomor } \\
\text { VIII.G.7 Kep- } \\
\text { 347/BL/2012, \& } \\
\text { Peraturan } \\
\text { Bapepam Nomor } \\
\text { X.K.6 Kep- } \\
\text { 431/BL/2012 }\end{array}$ & 2.97 \\
\hline & 5 & $\begin{array}{l}\text { Laporan Arus } \\
\text { Kas }\end{array}$ & $\begin{array}{l}\text { Memenuhi ketentuan sebagai } \\
\text { berikut: } \\
\text { 2. Penggunaan metode langsung } \\
\text { (direct method) untuk melaporkan } \\
\text { arus kas dari aktivitas operasi; } \\
\text { jelas dalam klasifikasi transaksi } \\
\text { yang sejenis }\end{array}$ & $\begin{array}{l}\text { Peraturan } \\
\text { Bapepam Nomor } \\
\text { VIII.G.7 Kep- } \\
\text { 347/BL/2012, \& } \\
\text { Peraturan } \\
\text { Bapepam Nomor } \\
\text { X.K.6 Kep- } \\
\text { 431/BL/2012 } \\
\text { PSAK 2 }\end{array}$ & 2.97 \\
\hline & 6 & $\begin{array}{l}\text { lkhtisar } \\
\text { Kebijakan } \\
\text { Akuntansi }\end{array}$ & $\begin{array}{l}\text { Meliputi sekurang-kurangnya: } \\
\text { 2. Dasar pengukuran dan } \\
\text { penyusunan laporan keuangan; } \\
\text { 3. Pengakuan pendapatan dan } \\
\text { beban; }\end{array}$ & $\begin{array}{l}\text { Peraturan } \\
\text { Bapepam Nomor } \\
\text { VIII.G.7 Kep- } \\
\text { 347/BL/2012, \& } \\
\text { Peraturan } \\
\text { Bapepam Nomor } \\
\text { X.K.6 Kep- } \\
\text { 431/BL/2012 }\end{array}$ & 2.97 \\
\hline & 7 & $\begin{array}{l}\text { Pengungkapan } \\
\text { yang } \\
\text { berhubungan } \\
\text { dengan aset } \\
\text { tetap }\end{array}$ & $\begin{array}{l}\text { Hal-hal yang harus diungkapkan:1. } \\
\text { Metode penyusutan yang } \\
\text { digunakan;2. Uraian mengenai } \\
\text { kebijakan akuntansi yang dipilih } \\
\text { antara model revaluasi dan model } \\
\text { biaya; }\end{array}$ & $\begin{array}{l}\text { Peraturan } \\
\text { Bapepam Nomor } \\
\text { VIII.G.7 Kep- } \\
\text { 347/BL/2012, \& } \\
\text { Peraturan } \\
\text { Bapepam Nomor } \\
\text { X.K.6 Kep- } \\
\text { 431/BL/2012PSAK } \\
\text { 16 }\end{array}$ & 2.97 \\
\hline
\end{tabular}




\begin{tabular}{|c|c|c|c|c|c|c|}
\hline \multicolumn{2}{|c|}{ Indikator } & \multicolumn{3}{|c|}{ Pertanyaan yang digunakan untuk mewakili Indikator } & \multirow[b]{2}{*}{\begin{tabular}{l}
\multicolumn{1}{c}{$\begin{array}{c}\text { Literature } \\
\text { sebelumnya }\end{array}$} \\
Peraturan \\
Bapepam Nomor \\
VIII.G.7 Kep- \\
347/BL/2012, \& \\
Peraturan \\
Bapepam Nomor \\
X.K.6 Kep- \\
431/BL/2012 \\
PSAK 5
\end{tabular}} & \multirow{2}{*}{$\begin{array}{l}\text { Maks } \\
\text { Point } \\
2.97\end{array}$} \\
\hline & & 8 & $\begin{array}{l}\text { Pengungkapan } \\
\text { yang } \\
\text { berhubungan } \\
\text { dengan segmen } \\
\text { operasi }\end{array}$ & $\begin{array}{l}\text { Hal-hal yang harus diungkapkan: } \\
\text { 2. Informasi tentang laba rugi, } \\
\text { aset, dan liabilitas segmen yang } \\
\text { dilaporkan; } \\
\text { 3. Rekonsiliasi dari total } \\
\text { pendapatan segmen, laba rugi } \\
\text { segmen yang dilaporkan, aset } \\
\text { segmen, liabilitas segmen, dan } \\
\text { unsur material segmen lainnya } \\
\text { terhadap jumlah terkait dalam } \\
\text { entitas; dan }\end{array}$ & & \\
\hline & & 9 & $\begin{array}{l}\text { Pengungkapan } \\
\text { yang } \\
\text { berhubungan } \\
\text { dengan } \\
\text { Instrumen } \\
\text { Keuangan }\end{array}$ & $\begin{array}{l}\text { Hal-hal yang harus diungkapkan: } \\
\text { 2. Nilai wajar tiap kelompok } \\
\text { instrumen keuangan; } \\
\text { 3. Kebijakan manajemen risiko; }\end{array}$ & $\begin{array}{l}\text { Peraturan } \\
\text { Bapepam Nomor } \\
\text { VIII.G.7 Kep- } \\
\text { 347/BL/2012, \& } \\
\text { Peraturan } \\
\text { Bapepam Nomor } \\
\text { X.K.6 Kep- } \\
\text { 431/BL/2012 } \\
\text { PSAK 50, 55 dan } \\
60 \\
\end{array}$ & 2.97 \\
\hline \multirow[t]{4}{*}{8} & \multirow[t]{4}{*}{ Understandability } & 1 & $\begin{array}{l}\text { Sampai sejauh } \\
\text { mana } \\
\text { penggunaan } \\
\text { bahasa dan } \\
\text { jargon teknis } \\
\text { dalam laporan } \\
\text { keuangan } \\
\text { mudah } \\
\text { untuk diikuti? } \\
\text { Dilihat dari } \\
\text { keterangan } \\
\text { tambahan dalam } \\
\text { perjanjian } \\
\text { penting }\end{array}$ & $\begin{array}{l}1 \text { = Banyak jargon (industry), tidak } \\
\text { dijelaskan } \\
2=\text { Banyak jargon, penejelasan } \\
\text { minimal } \\
3=\text { Jargon dijelaskan tersendiri } \\
4=\text { Tidak terlalu banyak jargon, } \\
\text { dijelasakn secara cukup } \\
5=\text { Tidak adajargon, penjelasan } \\
\text { yang sangat detail dan spesifik }\end{array}$ & $\begin{array}{l}\text { e.g. IASB, 2006; } \\
\text { Jonas } \\
\text { and Blanchet, } \\
2000 ; \text { lu } \\
\text { and Clowes, } 2004\end{array}$ & 2.97 \\
\hline & & 2 & $\begin{array}{l}\text { Laporan Arus } \\
\text { Kas }\end{array}$ & $\begin{array}{l}\text { Memenuhi ketentuan sebagai } \\
\text { berikut: } \\
\text { 1. Pengelompokan dalam tiga } \\
\text { kategori aktivitas: operasi, } \\
\text { investasi, dan pendanaan; } \\
\text { 2. Penggunaan metode langsung } \\
\text { (direct method) untuk melaporkan } \\
\text { arus kas dari aktivitas operasi; } \\
\text { jelas dalam klasifikasi transaksi } \\
\text { yang sejenis }\end{array}$ & $\begin{array}{l}\text { Peraturan } \\
\text { Bapepam Nomor } \\
\text { VIII.G.7 Kep- } \\
\text { 347/BL/2012, \& } \\
\text { Peraturan } \\
\text { Bapepam Nomor } \\
\text { X.K.6 Kep- } \\
\text { 431/BL/2012 } \\
\text { PSAK } 2\end{array}$ & 2.97 \\
\hline & & 3 & $\begin{array}{l}\text { Pengungkapan } \\
\text { yang } \\
\text { berhubungan } \\
\text { dengan aset } \\
\text { tetap }\end{array}$ & $\begin{array}{l}\text { Hal-hal yang harus diungkapkan: } \\
\text { 4. Rekonsiliasi jumlah tercatat } \\
\text { bruto dan akumulasi penyusutan } \\
\text { aset tetap pada awal dan akhir } \\
\text { periode dengan menunjukkan: } \\
\text { penambahan, pengurangan dan } \\
\text { reklasifikasi. }\end{array}$ & $\begin{array}{l}\text { Peraturan } \\
\text { Bapepam Nomor } \\
\text { VIII.G.7 Kep- } \\
\text { 347/BL/2012, \& } \\
\text { Peraturan } \\
\text { Bapepam Nomor } \\
\text { X.K.6 Kep- } \\
\text { 431/BL/2012 } \\
\text { PSAK } 16 \\
\end{array}$ & 2.97 \\
\hline & & 4 & $\begin{array}{l}\text { Pengungkapan } \\
\text { yang } \\
\text { berhubungan } \\
\text { dengan segmen } \\
\text { operasi }\end{array}$ & $\begin{array}{l}\text { Hal-hal yang harus diungkapkan: } \\
\text { 4. Pengungkapan pada level } \\
\text { entitas, yang meliputi informasi } \\
\text { tentang produk dan/atau jasa, } \\
\text { wilayah geografis dan pelanggan } \\
\text { utama. }\end{array}$ & $\begin{array}{l}\text { Peraturan } \\
\text { Bapepam Nomor } \\
\text { VIII.G.7 Kep- } \\
\text { 347/BL/2012, \& } \\
\text { Peraturan } \\
\text { Bapepam Nomor }\end{array}$ & 2.97 \\
\hline
\end{tabular}




\begin{tabular}{|c|c|c|c|c|c|c|}
\hline \multicolumn{2}{|r|}{ Indikator } & \multicolumn{3}{|c|}{ Pertanyaan yang digunakan untuk mewakili Indikator } & \multirow{2}{*}{\begin{tabular}{l}
\multicolumn{1}{c}{$\begin{array}{c}\text { Literature } \\
\text { sebelumnya }\end{array}$} \\
X.K.6 Kep- \\
431/BL/2012 \\
PSAK 5
\end{tabular}} & \multirow[t]{2}{*}{$\begin{array}{l}\text { Maks } \\
\text { Point }\end{array}$} \\
\hline & & & & & & \\
\hline \multirow[t]{2}{*}{9} & \multirow[t]{2}{*}{ Timeliness } & 1 & $\begin{array}{l}\text { Berapa hari } \\
\text { yang dibutuhkan } \\
\text { untuk auditor } \\
\text { untuk } \\
\text { menandatangani } \\
\text { laporan } \\
\text { keuangan } \\
\text { setelah tahun } \\
\text { buku berakhir? }\end{array}$ & $\begin{array}{l}\text { Periode hari } \\
1=>4 \text { bulan dari tanggal tutup } \\
\text { buku } \\
2=+-4 \text { bulan dari tanggal tutup } \\
\text { buku } \\
3=+-3 \text { bulan dari tanggal tutup } \\
\text { buku } \\
4=+-2 \text { bulan dari tanggal tutup } \\
\text { buku } \\
5=+-1 \text { bulan dari tanggal tutup } \\
\text { buku }\end{array}$ & e.g IASB, 2008 & 2.97 \\
\hline & & 2 & $\begin{array}{l}\text { Penerbitan } \\
\text { laporan } \\
\text { keuangan }\end{array}$ & $\begin{array}{l}\text { Hal-hal yang diungkapkan antara } \\
\text { lain: } \\
\text { 1. Tanggal laporan keuangan } \\
\text { diotorisasi untuk terbit; dan edisi } \\
\text { revisi } \\
\text { 2. Pihak yang bertanggung jawab } \\
\text { mengotorisasi laporan keuangan. }\end{array}$ & $\begin{array}{l}\text { Peraturan } \\
\text { Bapepam Nomor } \\
\text { VIII.G.7 Kep- } \\
\text { 347/BL/2012, \& } \\
\text { Peraturan } \\
\text { Bapepam Nomor } \\
\text { X.K.6 Kep- } \\
\text { 431/BL/2012 }\end{array}$ & 2.97 \\
\hline \multicolumn{6}{|c|}{$\begin{array}{l}\text { Total nilai } 22 \text { pertanyaan } \times \text { nilai max } 5=110 \text {, dibagi menjadi } 37 \text { point sehingga per point memiliki nilai } \\
\text { maks } 2.97\end{array}$} & 110 \\
\hline
\end{tabular}

